Jurnal Ekonomi Modernisasi

http://ejournal.unikama.ac.id/index.php/JEKO

JEM 12,2, (2016) 91-98

\title{
FAKTOR-FAKTOR KEBERHASILAN BADAN EKSEKUTIF MAHASISWA TELKOM UNIVERSITY
}

\author{
Astadi Pangarso \\ Program Studi Administrasi Bisnis, Fakultas Komunikasi \& Bisnis, Universitas Telkom \\ Jl. Telekomunikasi, No. 1, Bandung, Indonesia, 40257 \\ Syahputra \\ Program Studi Administrasi Bisnis, Fakultas Komunikasi \& Bisnis, Universitas Telkom \\ Jl. Telekomunikasi, No. 1, Bandung, Indonesia, 40257 \\ Grahatama Windhu Seto Perbowo \\ Program Studi Administrasi Bisnis, Fakultas Komunikasi \& Bisnis, Universitas Telkom \\ Jl. Telekomunikasi, No. 1, Bandung, Indonesia, 40257
}

\begin{abstract}
Telkom university is private university under telkom foundation. Student organisation are the ones consisted of college students to accommodate talent, interest and potential student who conducted at the extracurricular activities.The purpose of this research to know variable the most dominant of organisation factors success based the theory of schmuck. This research using 110 sample of the local the executive agency students telkom university, data collection use questionare.The kind of research this is descriptive analysis by approach kuantitaf.The analysis used is Confirmatory Factor Analysis (CFA). This research result indicates factors most dominant is a factor clarifying communication, on the dominant seven indicators that affects, the most dominant are the delivery of information about an event pertaining to work programs BEM fast.
\end{abstract}

Keywords: : success organization, clarifying communication, communicating information

DOI : http://dx.doi.org/10.21067/jem.v12i2.1194

Diterima : Februari 2016; April 2016; Diterima : Juni 2016

PENDAHULUAN

Organisasi dibentuk untuk menjadi wadah/wahana kegiatan dari orang-orang yang bekerjasama dalam usaha mencapai tujuan. Hal itu selaras dengan apa yang dikemukakan Dalton E. Mc. Farland (1959:10) "An organization is an identifiable group of people contributing their efforts toward the attainment of goals"

* Corresponding Author. astadipangarso@ telkomuniversity.ac.id
Organisasi adalah suatu kelompok manusia yang dapat dikenal yang menyumbangkan usahanya terhadap tercapainya suatu tujuan.

Badan Eksekutif Mahasiswa sebagai objek penelitian. BEM dipilih karena tujuan dan fungsi BEM yang bersentuhan langsung antara mahasiswa dengan Institusi, dan mahasiswa dengan masyarakat umum, selain itu keberadaan Badan Eksekutif Mahasiswa sebaga Lembaga Eksekutif mahasiswa yang menjadi penyambung lidah dan representatif mahasiswa, dan secara 
defacto juga sebagai kontrol berjalannya pemerintahan di dalam negara. Hal ini menunjukkan bahwa peran organisasi kemahasiswaan memiliki ruang lingkup yang berbeda sesuai konteks. Organisasi kemahasiswaan memiliki kemungkinan dampak yang cukup besar sampai ke lingkup pemerintahan suatu negara. Hal ini tentunya dapat terjadi apabila ruang lingkup universitas sudah berjalan dengan baik. Sedangkan dilihat dari penilaian kinerja hanya dinilai dari tingkat keberhasilan program kerja saja tidak mencangkup penilain internal organisasi.

Sebuah organisasi tidak diciptakan untuk menuai kegagalan begitu pula dengan Badan Eksekutif Mahasiswa. Dalam 2 tahun pertama berjalan Badan Eksekutif Mahasiswa dari observasi yang dilakukan penulis dan penulis terlibat langsung di BEM pada tahun pertama dalam 2 tahun ini BEM Telkom University mengalami kemajuan yang cukup signifikan terbukti dengan :

a. Peningkatan Softskill mahasiswa.

b. Semakin sinergi hubungan Institusi dengan Mahasiswa terbukti dengan tidak adanya konflik antara Mahasiswa dengan Institusi seperti di tahun pertama Telkom University dan BEM Tel-U.

c. Semakin terwadahinya bakat minat Mahasiswa dengan semakin bertumbuhnya UKM dan Komunitas (Data dari BEM KEMA pertumbuhan UKM dan Komunitas sebesar 15\% dari Tahun pertama). Semakin banyaknya acara olahraga dan seni yang melibatkan unsure civitas Tel-U.

d. Peningkatan kemampuan pengurus organisasi terihat dari semakin rapi dan teroganisirnya kegiatan BEM.

e. Semakin banyak acara sosial yang hanya melibatkan warga sekitar hingga masyarakat luas pada umumnya.

Semakin di dengarnya kritik saran mahasiswa kepada pemerintah dibuktikan dengan di undangnya perwakilan BEM Tel-U untuk berdiskusi dengan Presiden RI.

\section{TINJAUAN PUSTAKA}

Menurut Cyrill Soffer dalam Subkhi 2013 Organisasi adalah perserikatan orang-orang yang masing-masing diberi peran tertentu dalam suatu sistem kerja dan pembagian dimana pekerjaan itu di perinci menjadi tugas-tugas, dibagikan kemudian digabung lagi dalam beberapa bentuk hasil. "Manusia diciptakan untuk menjadi makhluk sosial.Keterbatasan manusia dalam memenuhi kebutuhan untuk bertahan hidup sering di artikan sebagi hubungan sosial. Organisasi sosial secara sadar dikoordinasikan dengan mempunyai dasar kerja untuk mencapai tujuan bersama" (Pangarso, 2014).

Menurut UU nomor 12 tahun 2012 tentang pendidikan tinggi pasal 77 menyatakan bahwa (1) Mahasiswa dapat membentuk organisasi kemahasiswaan. (2) Orgainasi kemahasiswaan paling sedikit memiliki fungsi untuk :

a. Mewadahi kegiatan mahasiswa dalam mengembangkan bakat, minat, dan potensi mahasiswa

b. Mengembangkan kreativitas, kepekaan, daya kritis, keberanian, dan kepemimpinan, serta rasa kebangsaan

c. Memenuhi kepentingan dan kesejahteraan mahasiswa dan

d. Mengembangkan kegiatan pengabdian kepada masyarakat

(3) Organisasi kemahasiswaan sebagaimana dimaksud pada ayat (1) merupakan organisasi intra perguruan tinggi. (4) Perguruan tinggi menyediakan sara dan prasarana serta dana untuk mendukung kegiatan organisasi kemahasiswaan. Menambahkan UU nomor 12 tahun 2012 menurut keputusan menteri pendidikan dan kebudayaan tentang pedoman umum organisasi kemahasiswaaan di peguruan tinggi tahun 1998 Bab 1 pasal 1 poin 1 "Organisasi kemahasiswaan intra perguruan tinggi adalah wahana dan sarana pengembangan diri mahasiswa ke arah perluasan wawasan dan peningkatan kecendikiawanan serta integritas kepribadian untuk mencapai tujuan pendidikan tinggi. Organisasi kemahasiswaan di perguruan tinggi diselenggarakan berdasarakan prinsip dari, oleh dan untuk mahasiswa dengan memberikan 
peranan dan keleluasaan lebih besar kepada mahasiswa".

Menurut Schmuck et al. (1979) dalam Soetopo (2010) terdapat beberapa faktor yang mempengaruhi keberhasilan organisasi sebagai berikut :

b. Establishing goals (pencapaian tujuan)
c. Uncovering conflicts and interdepence (penyelasian konflik)
d. Improving group procedure (meningkatkan prosedur kelompok)

e. Problem Solving (pemecahan masalah)

f. Making decisions (pembuatan keputusan)

g. Assessing changes (menilai perubahan)

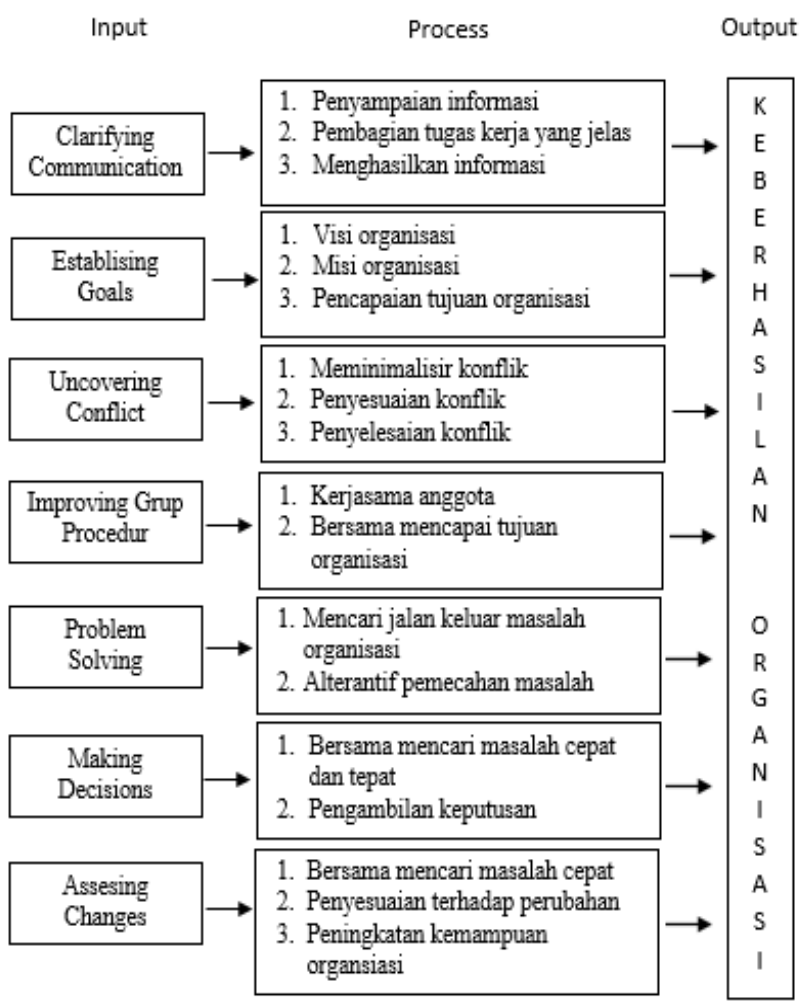

Gambar 1. Kerangka Pemikiran

\section{METODE}

Jenis penelitian yang digunakan adalah analisis deskriptif dengan pendekatan kuantitatif. Analisis yang digunakan pada penelitian ini adalah Confirmatory Factor Analysis (CFA).
Untuk perhitungan sampel dari jumlah pengurus populasi sebanyak 264 pengurus organisasi maka penulis menggunakan tingkat keslahan sebesar 10\%. Dengan demikian jumlah sampelnya.

$$
n=\frac{N}{1+N\left(e^{2}\right)}=\frac{264}{1+264(0,1)^{2}}=\frac{264}{1+2,64}=\frac{264}{3,64}=72,52 \approx 73
$$

Dari hasil penghitungan menggunakan rumus Slovin diatas didapat sampel sebanyak 73 orang. Untuk mengantispasi responden yang asal jawab dan untuk lebih mendapatkan hasil yang lebih akurat penulis menambah jumlah sampel sebanyak $50 \%$ dengan perhitungan sebagai berikut:

[ jumlah sampel $+50 \%$ dari jumlah sampel $=73$ $+36,5=109,5 \approx 110]$

Maka total jumlah sampel yang akan digunakan dalam penelitian ini adalah 110 orang.

Dalam menentukan proporsi sampel penulis menggunakan rumus dalam (Sugiyono, 2007)

$$
n_{1}-\frac{n}{N} N_{1}
$$

$n_{1}=$ Banyak sampel dalam tiap organisasi

$\mathrm{n}=$ Banyak populasi dalam tiap organisasi

$\mathrm{N}=$ Banyak populasi seluruh organisasi

$N_{1}=$ Banyaknya sampel penelitian

Tabel 1

Proporsi Sampel Berdasarkan Jumlah Populasi

\begin{tabular}{cccc}
\hline NO & BEM & $\begin{array}{c}\text { Jumlah } \\
\text { Pengurus }\end{array}$ & $\begin{array}{c}\text { Proporsi } \\
\text { Sampel }\end{array}$ \\
\hline 1 & BEM KEMA & 93 & 39 \\
2 & BEM FEB & 54 & 23 \\
3 & BEM FKB & 40 & 17 \\
4 & BEM FIT & 43 & 18 \\
5 & BEM FIK & 30 & 13 \\
& JUMLAH & 264 & 110 \\
\hline
\end{tabular}

\section{HASIL}

Analisis faktor digunakan untuk mengidentifikasi faktor-faktor yang mempengaruhi keberhasilan organisasi pada 
Badan Eksekutif Mahasiswa Telkom University. Pengolahan analisis faktor dilakukan dengan menggunakan Software SPSS.

Tabel communalities pada dasarnya adalah jumlah varian suatu variabel mula-mula yang bisa dijelaskan oleh faktor yang ada. Berdasarkan tabel 4 (lampiran) yaitu faktor menunjukkan angka 0,807. semakin besar angka Extraction sebuah variabel maka semakin erat hubungan dengan faktor yang menjadi dasar awal penelitian.

Data ditampilkan sampai faktor 15 dari 34 faktor. Dari perhitungan tersebut, total dari tujuh faktor akan bisa menjelaskan $71,143 \%$ dari 34 faktor asli. Dari tabel terlihat terbentuk tujuh component atau faktor hal tersebut sesuai denagn jumlah component awal yang menjadi dasar penelitian.

Pada pengolahan data diatas hanya ditampilkan hasil >0,50. Rotation Matrix memperlihatkan distribusi indikator yang jelas dan nyata sesuai dengan faktornya masingmasing yang sudah ditentukan.Metode rotasi yang digunakan dalam penelitian ini adalah Varimax. Pada tabel 4.4 terlihat semua variabel terdistribusi pada faktor yang telah ditentukan.

\section{PEMBAHASAN}

Penelitian ini bertujuan untuk menentukan faktor yang paling dominan pada keberhasilan Badan Eksekutif Mahasiswa Telkom University periode januari 2015 sampai dengan desember 2015 berdasarkan teori Schmuck. Dalam menentukan faktor dominan, yang perlu diperhatikan adalah nilai eigenvalues faktor yang terbesar. Dapat disimpulkan bahwa faktor yang paling dominan dalam keberhasilan Badan Eksekutif Mahasiswa Telkom university periode Januari 2015 sampai dengan Desember 2015 adalah faktor Clarifying Communication.

Di dalam Clarifying Communication terdapat indikator yang mempengaruhi keberhasilan faktor tersebut, untuk melihat indikator yang paling berpengaruh diambil nilai dari nilai communalities yang mana communalities menunjukan hubungan keeratan indikator terhadap faktor. Suatu indikator dapat diartikan memiliki keeratan dengan faktor apabila mempunyai nilai communalities $>0,5$ dan akan makin bagus atau makin erat apabila semakin mendekati nilai 1,0. Beberapa hal terkait dengan faktor dominan dalam clarifying communication, meliputi :

1. Penyampaian informasi tentang suatu kejadian yang berkaitan dengan program kerja BEM jelas, memiliki nilai communalities sebesar 0,801 , yang berarti bahwa indikator ini memiliki keerat hubungan dengan faktor clarifying communication.

2. Penyampaian informasi tentang suatu kejadian yang berkaitan dengan program kerja BEM cepat, memiliki nilai communalities sebesar 0,842 , yang berarti bahwa indikatot ini memiliki keratin hubungan dengan faktor clarifying communication sekaligus indikator ini memiliki nilai keeratan tertinggi dari indikator lain pada faktor clarifying communication

3. Pembagian tugas dilakukan secara jelas, memiliki nilai communalities sebesar 0,832 , yang berarti bahwa indikator ini memiliki keeratan hubungan dengan faktor clarifying communication

4. Tugas dilaksanakan benar (sesuai aturan), memiliki nilai communalities sebesar 0,658 yang berarti bahwa indikator ini memiliki keertan hubungan dengan faktor clarifying communication.

5. Tugas dilaksanakan tepat waktu, memiliki nilai communalities sebesar 0,736 yang berarti bahwa indikator ini memiliki keeratan hubungan dengan faktor clarifying communication

6. Informasi yang disampaikan dapat dipahami, memiliki nilai communalities sebesar 0,721 yang berarti bahwa indikator ini memiliki keeratan hubungan dengan faktor clarifying communication.

7. Informasi yang diterima akurat (sesuai kenyataan), memiliki nilai communalities 0,606 yang berarti bahwa indikator ini memiliki keeratan hubungan dengan faktor clarifying communication. 


\section{SIMPULAN DAN SARAN Simpulan}

Berdasarkan hasil dari proses pengolahan data menggunakan metode konfirmatori faktor dapat diambil kesimpulkan bahwa ketujuh faktor menurut teori Schmuck mampu mewakili atau berkontribusi $71.47 \%$ kepada keberhasilan Badan Eksekutif Mahasiswa Telkom University periode Januari 2015 sampai dengan Desember 2015, Tabel 5 (Lampiran).

Kesimpulan utama dari penelitian ini yang berdasarkan hasil analisis dapat diketahu bahwa faktor yang paling dominan terhadap keberhasilan organisasi Badan Eksekutif Mahasiswa Telkom University adalah faktor Clarifying Communication yang memiliki nilai Intial Eigenvalues sebesar 29.543\%.

Berdasarkan hasil penelitian dan analisis yang telah dilakukan, maka peneliti memberikan beberapa saran, anatara lain:

\section{Saran}

Saran bagi Pengurus BEM Telkom University :

Hendaknya para pengurus BEM lebih intensif dalam melakukan komunikasi untuk menghindari kesalahan persepsi yang nantinya akan menimbulkan konflik dan menghambat kinerja BEM., selain itu Ketua/Wakil/Kadept harus memberikan tugas kepada anggotanya sejelas mungkin untuk menghasilkan output yang sesuai dengan tujuan awal, Dalam menjalin komunikasi antar anggota hendaknya menggunakan media yang mampu menjagkau seluruh anggota.

\section{Bagi Penelitian Selanjutnya}

Bagi penelitian selanjutnya yang akan mengkaji lebih dalam tentang penelitian ini diharapkan hasil penelitian ini dapat menjadi salah satu sumber informasi yang akan digunakan sebagai referensi agar organisasi mahasiswa dapat melakukan kegiatannya dengan efektif dan efisien.
Penelitian selanjutnya bisa lebih melakukan eksplorasi terhadap faktor mapu lebih berkontribusi pada keberhasilan organisasi untuk mendapatkan hasil lebih baik.

\section{Saran Bagi Institusi :}

Telkom University sebagai lembaga yang menaungi BEM harus lebih memfasilitasi dan mendukung dalam bentuk non-Material atau material mengingat pentingnya fungsi BEM bagi mahasiswa, Institusi dan Masyarakat luas pada umumnya.

Telkom university sebagai lembaga yang menaungi BEM harus mempunyai data mengenai program kerja BEM sehingga institusi dapat memberikan saran dan masukan terhadap BEM sehingga bisa berjalan selaras.

\section{DAFTAR PUSTAKA}

Farland, Dalton E.Mc. 1959. Management Principles and Practices. New York, MacMillan.

Pangarso, Astadi. 2014. Organization's structure based on competing value approach and merger strategy, Bandung

Santoso, Singgih. 2014. Statistik Multivariat Konsep dan Aplikasi dengan SPSS.Jakarta : PT Elex Media Komputindo

Soetopo, Hendayat, 2012. Perilaku Organisai Teori dan Praktek di Bidang Pendidikan. Bandung : PT. Remaja Rosda Karya

Subkhi, Akhmad. 2013. Pengantar Teori dan Perilaku organisasi. Jakarta :Prestasi Pustaka.

Sugiyono. (2014). Metode Penelitian Manajemen. Bandung : Alfabeta.

UU nomor 12 tahun 2012 tentang pendidikan tinggi pasal 77 
Tabel 2.

KMO and Bartlett's Test

\begin{tabular}{lrr}
\hline Kaiser-Meyer-Olkin Measure of Sampling Adequacy & .715 \\
Bartlett's Test of Sphericity & Approx. Chi- Square & 3176.146 \\
& df & 561 \\
& Sig. & .000 \\
\hline
\end{tabular}

Tabel 3

Anti Image Matrices

\begin{tabular}{llllll}
\hline No & Indikator & MSA & No & Indikator & MSA \\
\hline 1 & komunikasi_1 & 0,791 & 18 & penyelesaian_5 & 0,524 \\
2 & komunikasi_2 & 0,803 & 19 & prosedur_1 & 0,649 \\
3 & komunikasi_3 & 0,821 & 20 & prosedur_2 & 0,522 \\
4 & komunikasi_4 & 0,797 & 21 & prosedur_3 & 0,633 \\
5 & komunikasi_5 & 0,803 & 22 & prosedur_4 & 0,687 \\
6 & komunikasi_6 & 0,810 & 23 & pemecahan_1 & 0,740 \\
7 & komunikasi_7 & 0,822 & 24 & pemecahan_2 & 0,564 \\
8 & pencapaian_1 & 0,811 & 25 & pemecahan_3 & 0,623 \\
9 & pencapaian_2 & 0,572 & 26 & pemecahan_4 & 0,633 \\
10 & pencapaian_3 & 0,566 & 27 & pembuatan_1 & 0,825 \\
11 & pencapaian_4 & 0,826 & 28 & pembuatan_2 & 0,551 \\
12 & pencapaian_5 & 0,919 & 29 & pembuatan_3 & 0,835 \\
13 & pencapaian_6 & 0,697 & 30 & pembuatan_4 & 0,678 \\
14 & penyelesaian_1 & 0,722 & 31 & menilai_1 & 0,726 \\
15 & penyelesaian_2 & 0,657 & 32 & menilai_2 & 0,630 \\
16 & penyelesaian_3 & 0,568 & 33 & menilai_3 & 0,618 \\
17 & penyelesaian_4 & 0,726 & 34 & menilai_4 & 0,640 \\
\hline
\end{tabular}

Tabel 4

Communalities

\begin{tabular}{lrrrrr}
\hline Indikator & Initial & Extraction & \multicolumn{1}{c}{ Indikator } & Initial & Extraction \\
\hline komunikasi_1 & 1,000 &, 807 & penyelesaian_5 & 1,000 &, 611 \\
komunikasi_2 & 1,000 &, 842 & prosedur_1 & 1,000 &, 629 \\
komunikasi_3 & 1,000 &, 832 & prosedur_2 & 1,000 &, 650 \\
komunikasi_4 & 1,000 &, 658 & prosedur_3 & 1,000 &, 704 \\
komunikasi_5 & 1,000 &, 736 & prosedur_4 & 1,000 &, 532 \\
komunikasi_6 & 1,000 &, 721 & pemecahan_1 & 1,000 &, 738 \\
komunikasi_7 & 1,000 &, 606 & pemecahan_2 & 1,000 &, 704 \\
pencapaian_1 & 1,000 &, 771 & pemecahan_3 & 1,000 &, 737 \\
pencapaian_2 & 1,000 &, 702 & pemecahan_4 & 1,000 &, 573 \\
pencapaian_3 & 1,000 &, 721 & pembuatan_1 & 1,000 &, 715 \\
pencapaian_4 & 1,000 &, 772 & pembuatan_2 & 1,000 &, 793 \\
pencapaian_5 & 1,000 &, 715 & pembuatan_3 & 1,000 &, 804 \\
pencapaian_6 & 1,000 &, 738 & pembuatan_4 & 1,000 &, 790 \\
penyelesaian_1 & 1,000 &, 651 & menilai_1 & 1,000 &, 692 \\
penyelesaian_2 & 1,000 &, 681 & menilai_2 & 1,000 &, 735 \\
penyelesaian_3 & 1,000 &, 505 & menilai_3 & 1,000 &, 799 \\
penyelesaian_4 & 1,000 &, 844 & menilai_4 & 1,000 &, 682 \\
\hline
\end{tabular}




\section{Lampiran}

Tabel 5

Total Variance

Total Variance Explained

\begin{tabular}{|c|c|c|c|c|c|c|c|c|c|c|c|c|}
\hline \multicolumn{2}{|c|}{ Component } & \multirow{2}{*}{\multicolumn{2}{|c|}{$\begin{array}{l}\text { Initial Eigenvalues } \\
\% \text { of Variance }\end{array}$}} & \multicolumn{4}{|c|}{ Extraction Sums of Squared Loadings } & \multicolumn{3}{|c|}{ Rotation Sums of Squared Loadings } & \multirow{3}{*}{$\%$ of Variance } & \multirow{3}{*}{ Cumulative \% } \\
\hline \multirow[b]{2}{*}{1} & \multirow{2}{*}{$\begin{array}{l}\text { Total } \\
10.044\end{array}$} & & & \multicolumn{2}{|c|}{ Cumulative \% } & \multirow{2}{*}{$\begin{array}{l}\text { Total } \\
29.543\end{array}$} & \multicolumn{2}{|c|}{$\%$ of Variance } & \multirow{2}{*}{$\begin{array}{l}\text { Cumulative \% } \\
17.172\end{array}$} & \multirow[t]{2}{*}{ Total } & & \\
\hline & & 29.543 & 29.543 & 10.04 & 29.543 & & 5.838 & 17.172 & & & & \\
\hline 2 & 3.979 & 11.702 & 41.245 & 3.979 & 11.702 & 41.245 & 4.435 & 13.044 & 30.216 & & & \\
\hline 4 & 2.276 & 6.695 & 55.621 & 2.276 & 6.695 & 55.621 & 2.895 & 8.514 & 47.582 & & & \\
\hline 5 & 2.172 & 6.389 & 62.01 & 2.172 & 6.389 & 62.01 & 2.859 & 8.408 & 55.99 & & & \\
\hline 6 & 1.663 & 4.891 & 66.901 & 1.663 & 4.891 & 66.901 & 2.846 & 8.372 & 64.362 & & & \\
\hline 7 & 1.555 & 4.573 & 71.474 & 1.555 & 4.573 & 71.474 & 2.418 & 7.113 & 71.474 & & & \\
\hline 8 & 1.183 & 3.479 & 74.953 & & & & & & & & & \\
\hline 9 & 0.986 & 2.899 & 77.852 & & & & & & & & & \\
\hline 10 & 0.863 & 2.54 & 80.391 & & & & & & & & & \\
\hline 11 & 0.751 & 2.209 & 82.6 & & & & & & & & & \\
\hline 12 & 0.675 & 1.985 & 84.584 & & & & & & & & & \\
\hline 13 & 0.641 & 1.884 & 86.469 & & & & & & & & & \\
\hline 14 & 0.555 & 1.632 & 88.101 & & & & & & & & & \\
\hline 15 & 0.505 & 1.486 & 89.587 & & & & & & & & & \\
\hline 17 & 0.419 & 1.232 & 92.13 & & & & & & & & & \\
\hline 18 & 0.374 & 1.1 & 93.23 & & & & & & & & & \\
\hline 19 & 0.342 & 1.007 & 94.237 & & & & & & & & & \\
\hline 20 & 0.324 & 0.954 & 95.191 & & & & & & & & & \\
\hline 21 & 0.258 & 0.759 & 95.95 & & & & & & & & & \\
\hline 22 & 0.236 & 0.693 & 96.643 & & & & & & & & & \\
\hline 23 & 0.175 & 0.514 & 97.158 & & & & & & & & & \\
\hline 24 & 0.17 & 0.501 & 97.659 & & & & & & & & & \\
\hline 25 & 0.143 & 0.422 & 98.081 & & & & & & & & & \\
\hline 26 & 0.114 & 0.334 & 98.415 & & & & & & & & & \\
\hline 27 & 0.106 & 0.312 & 98.726 & & & & & & & & & \\
\hline 28 & 0.092 & 0.271 & 98.998 & & & & & & & & & \\
\hline 29 & 0.092 & 0.27 & 99.268 & & & & & & & & & \\
\hline
\end{tabular}


Lampiran

Tabel 6

Rotated Component Matrix ${ }^{\mathrm{a}}$

\begin{tabular}{|c|c|c|c|c|c|c|}
\hline \multicolumn{7}{|c|}{ Component } \\
\hline 1 & 2 & 3 & 4 & 5 & 6 & 7 \\
\hline komunikasi_1 & 0.801 & & & & & \\
\hline komunikasi_2 & 0.877 & & & & & \\
\hline komunikasi_3 & 0.873 & & & & & \\
\hline komunikasi_4 & 0.787 & & & & & \\
\hline komunikasi_5 & 0.819 & & & & & \\
\hline komunikasi_6 & 0.811 & & & & & \\
\hline komunikasi_7 & 0.703 & & & & & \\
\hline pencapaian_1 & & 0.650 & & & & \\
\hline pencapaian_2 & & 0.724 & & & & \\
\hline pencapaian_3 & & 0.729 & & & & \\
\hline pencapaian_4 & & 0.716 & & & & \\
\hline pencapaian_5 & & 0.758 & & & & \\
\hline pencapaian_6 & & 0.710 & & & & \\
\hline penyelesaian_1 & & & 0.612 & & & \\
\hline penyelesaian_2 & & & 0.630 & & & \\
\hline penyelesaian_3 & & & 0.695 & & & \\
\hline penyelesaian_4 & & & 0.750 & & & \\
\hline penyelesaian_5 & & & 0.522 & & & \\
\hline prosedur_1 & & & & 0.710 & & \\
\hline prosedur_2 & & & & 0.734 & & \\
\hline prosedur_3 & & & & 0.774 & & \\
\hline prosedur_4 & & & & 0.649 & & \\
\hline pemecahan_1 & & & & & 0.680 & \\
\hline pemecahan_2 & & & & & 0.714 & \\
\hline pemecahan_3 & & & & & 0.767 & \\
\hline pemecahan_4 & & & & & 0.699 & \\
\hline pembuatan_1 & & & & & & 0.547 \\
\hline pembuatan_2 & & & & & & 0.874 \\
\hline pembuatan_3 & & & & & & 0.557 \\
\hline pembuatan_4 & & & & & & 0.750 \\
\hline menilai_1 & & & & & & 0.579 \\
\hline menilai_2 & & & & & & 0.704 \\
\hline menilai_3 & & & & & & 0.683 \\
\hline menilai_4 & & & & & & 0.648 \\
\hline
\end{tabular}

